\title{
Pulp Nonfiction
}

\section{Janis Butler Holm}

\begin{abstract}
Dans ce court texte, la narratrice applique les règles de la fiction à l'agression sexuelle. L'approche du prédateur est aussi subtile qu'une intrigue banale; la femme se fige dans un moment de suspense; sa réaction constitue le revirement narratif; elle vit mais "sera pour toujours malheureuse". Dans le dernier paragraphe, la narratrice compare cette histoire à d'autres et pose cette question: en demandant pourquoi de telles histoires existent, transgresse-t-on un «code artistique»?
\end{abstract}

He has stepped from a dark waiting place. He has moved toward her body with the crude insistence of a bad plot.

Her mind is stopped. She is fixed in the wisdom of stories learned too well: $\mathrm{Be}$ calm. It is inevitable. Do not struggle. He will only hurt you more.

For one long moment she stands mute, without motion. She could die of suspense. Then (here's the reversal) her pen is in her hand and stabbing through his flesh.

Unhappy ever after, she will live to confess how the fury in her throat exploded red and harsh and howling.

This story, like the others, is ugly and raw. It speaks a kind of wisdom. If I ask why we have such stories, such wisdoms, will I breach some artful code? Will I violate some expectation? 